\title{
Ophthalmic Pterygium
}

\section{A Stem Cell Disorder with Premalignant Features}

\author{
Jeanie Chui, ${ }^{*}$ Minas T. Coroneo, ${ }^{\dagger \ddagger}$ Lien T. Tat, ${ }^{\ddagger}$ \\ Roger Crouch, ${ }^{\S}$ Denis Wakefield, ${ }^{*}$ \\ and Nick Di Girolamo* \\ From the Inflammation and Infection Research Centre," School \\ of Medical Sciences, University of New South Wales, Sydney; the \\ Department of Ophthalmology, ${ }^{\dagger}$ and the South Eastern Area \\ Laboratory Services, ${ }^{\S}$ Prince of Wales Hospital, Randwick, \\ Sydney; and Ophthalmic Surgeons, ${ }^{\ddagger}$ Randwick, Sydney, \\ Australia
}

Pterygia are common ocular surface lesions thought to originate from limbal stem cells altered by chronic UV exposure. Traditionally regarded as a degenerative condition, pterygia also display tumor-like features, such as a propensity to invade normal tissue and high recurrence rates following resection, and may coexist with secondary premalignant lesions. This study was initiated to determine the rate of concurrent ocular surface diseases in patients with pterygia recruited from the practice of a single surgeon operating in a Sydney metropolitan hospital. One hundred pterygium specimens were histopathologically reviewed and selected cases were immunohistochemically assessed to confirm diagnosis. Along with previously documented typical features including epithelial proliferation, goblet cell hyperplasia, angiogenesis, inflammation, elastosis, stromal plaques, and Bowman's membrane dissolution, we identified five cases of ocular surface squamous neoplasia, six cases of primary acquired melanosis, two compound nevi (one suspect invasive melanoma), and one dermoid-like lesion. In 18 specimens, clusters of basal epithelial cells that coexpressed cytokeratin15/-19 and p63- $\alpha$ were identified at the head of the pterygium, coinciding with clinical observation of Fuchs' flecks. Our data show that significant preneoplastic lesions may be associated with pterygium and that all excised pterygia should undergo histological examination. The presence of p63- $\alpha$-positive epithelial cell clusters supports the hypothesis that pterygia develop from limbal epithelial progenitors. (Am J Pathol 2011, 178:817-827; DOI: 10.1016/j.ajpath.2010.10.037)
Pterygium is a wing-shaped ocular surface lesion traditionally described as an encroachment of bulbar conjunctiva onto the cornea. ${ }^{1}$ Historically, pterygia were considered degenerative lesions, exemplified by degradation of Bowman's layer and elastosis. Currently, however, pterygia are described as a proliferative disorder resembling an aberrant wound healing response. ${ }^{2}$ Histopathologically, pterygia are characterized by a hyperplastic, centripetally directed growth of altered limbal epithelial cells accompanied by Bowman's layer dissolution, epithelialmesenchymal transition, and an activated fibroblastic stroma with inflammation, neovascularization, and matrix remodeling, mediated through the concerted actions of cytokines, growth factors, and matrix metalloproteinases. ${ }^{2-9}$ Despite advances in understanding of its pathogenesis, pterygium remains an ophthalmic enigma. Intriguingly, pterygia have a predilection for the nasal limbus and affect only humans, possibly reflecting the unique ocular morphology of humans, compared with nonhuman primates and other animals. ${ }^{10}$ Although there is no consensus regarding the pathogenesis of pterygia, epidemiological evidence, ${ }^{11-14}$ its association with sun-related disorders such as pinguecula and cataracts, ${ }^{15}$ climatic droplet keratopathy, ${ }^{16}$ and squamous cell and basal cell carcinomas, ${ }^{17,18}$ together with our in vitro studies, ${ }^{5-8}$ support the concept that UV radiation plays a major role in development of pterygium. ${ }^{19}$ Furthermore, the limbal predilection may be explained by the phenomenon of peripheral light focusing, in which incidental light passes through the anterior chamber and is focused at the distal (nasal) limbus where limbal stem cells (LSCS) reside. ${ }^{20}$

A healthy corneal surface is maintained by self-renewing, lineage-specific stem cells (SCs) that reside in the limbus, a narrow annular transition zone that circumscribes the cornea. This regenerative capacity is regulated by exquisite programs that govern stem cell quiescence, proliferation,

Supported by a Career Development award (no. 455358, to N.D.) from the National Health and Medical Research Council of Australia.

Accepted for publication October 14, 2010.

Address reprint requests to Nick Di Girolamo, Ph.D., Inflammation and Infection Research Centre, School of Medical Sciences, University of New South Wales, Sydney, 2052 NSW, Australia. E-mail: n.digirolamo@unsw. edu.au. 

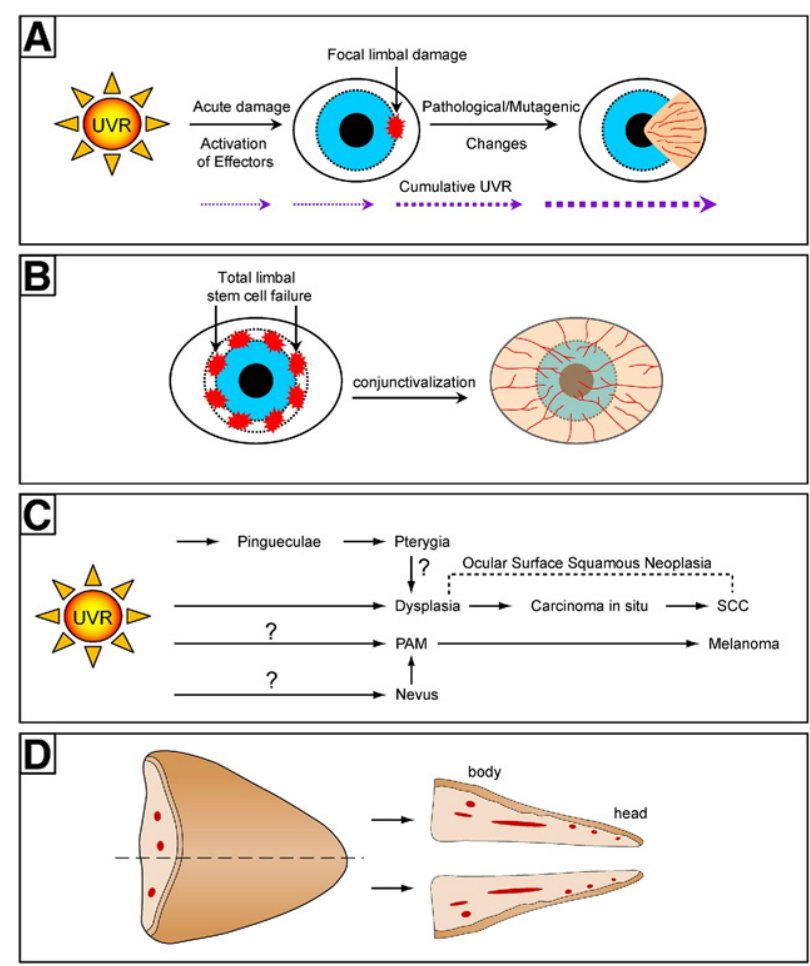

Figure 1. The role of cumulative UV radiation exposure in pterygium development. A: Model for the pathogenesis of pterygium: focal limbal damage from UV radiation triggers migration of altered LSCs toward the central cornea. B: In total LSC deficiency, damage to the limbal niche or depletion of stem cell reserves results in conjunctivalization of the cornea from all directions. C: Model of how ocular surface squamous neoplasia and melanoma might arise from pterygia. Question marks with pathways indicate absence of direct supporting clinical or experimental evidence. D: Bisection and orientation of pterygium specimens as assessed in the current study.

migration, and differentiation. Failure to maintain a normal microenvironment as a result of extrinsic (eg, UV radiation) or intrinsic (eg, cytokines) signals can result in the development of ocular disorders. ${ }^{2-6,19,21,22}$ The importance of an intact limbus and its stem cells was recognized four decades ago by Davanger and Evensen, ${ }^{23}$ who proposed that pterygia represent a specific zone of LSC deficiency. Our hypothesis for pterygium development takes into account peripheral light focusing 2,9,19,20 at the nasal limbus, which activates and/or mutates LSCs, resulting in clonal expan- sion, local cell proliferation, and invasion into the cornea (Figure 1A). Alternatively, focal UV radiation may destroy the LSC repository, which acts as a barrier that segregates cornea from conjunctiva, thereby opening the flood gates for conjunctival ingress and pterygium formation. Furthermore, an intrinsic weakness in the LSC reserves is implied by less prominent limbal palisades in the nasal and temporal limbus, ${ }^{24,25}$ suggesting that these regions might be more susceptible to damage and less likely to undergo effective repair. An analogous mechanism may occur in patients with total LSC deficiency, ${ }^{26}$ in which the absence of LSCs allows conjunctival invasion of the cornea to occur from 360 degrees (Figure 1B). In support of this posit, consecutive rounds of limbal excision affected wound healing, encouraged neovascularization, and promoted conjunctival ingress in rabbit corneas. ${ }^{27}$

Ophthalmologists have traditionally regarded pterygia as benign lesions, because they grow slowly. Unless a pterygium is sufficiently large as to obscure the visual axis or causes astigmatism, decisions to treat are often based on a patient's cosmetic concerns. An argument against this view, however, is the local invasiveness and high rate of recurrence when pterygia are inappropriately managed. ${ }^{28}$ Current management strategies for pterygia involve surgical excision, followed by wound closure with grafts or by application of adjunctive therapy to the bare scleral bed. ${ }^{29,30}$ Once excised, pterygia are commonly discarded without histological evaluation. This practice is not recommended, in the face of reported identification of unsuspected and potentially malignant secondary disorders in association with pterygia $^{31-33}$ (Table 1). These studies suggest that pterygia might have the propensity to evolve into precursors of squamous cell carcinoma and malignant melanoma of the ocular surface (Figure 1C).

In this study, we examined the histopathology of pterygia from patients treated by a single surgeon operating in a metropolitan hospital in Sydney, Australia. Histological features of pterygia and concurrent ocular diseases were recorded. All unusual cases were reviewed by an experienced anatomical pathologist and were further investigated by immunohistochemical methods. Additionally, we describe novel cell clusters in some pterygia that expressed putative LSC markers.

Table 1. Premalignant Ocular Disease Reported in Association with Pterygium and Pinguecula

\begin{tabular}{|c|c|c|c|c|c|}
\hline References & Study population & Tissues & Sample size & $\begin{array}{l}\text { Associated ocular } \\
\text { disease }\end{array}$ & $\%$ \\
\hline Sevel and Sealy ${ }^{31}$ & Cape Town, South Africa & pterygia & $n=100$ & $\begin{array}{l}\text { squamous cell carcinoma } \\
\text { carcinoma in situ }\end{array}$ & $\begin{array}{l}12 \\
17\end{array}$ \\
\hline Clear et al ${ }^{17}$ & Malawi & $\begin{array}{l}\text { pinguecula and } \\
\text { pterygia }\end{array}$ & $n=167$ & $\begin{array}{l}\text { hyperplasia or mild } \\
\quad \text { dysplasia } \\
\text { moderate dysplasia } \\
\text { carcinoma in situ }\end{array}$ & $\begin{array}{l}75.4 \\
11.4 \\
12.6\end{array}$ \\
\hline $\begin{array}{l}\text { Erie et } \mathrm{al}^{34} \\
\text { Perra et } \mathrm{al}^{33}\end{array}$ & $\begin{array}{l}\text { Mayo Clinic, Minnesota } \\
\text { Ecuador }\end{array}$ & $\begin{array}{l}\text { pterygia } \\
\text { pterygia }\end{array}$ & $\begin{array}{l}n=92 \\
n=80\end{array}$ & $\begin{array}{l}\text { carcinoma in situ } \\
\text { PAM without atypia } \\
\text { PAM with atypia } \\
\text { nevi }\end{array}$ & $\begin{array}{l}9.8 \\
6.3 \\
2.5 \\
2.5\end{array}$ \\
\hline Hirst et $\mathrm{al}^{32}$ & Queensland, Australia & pterygia & $n=533$ & OSSN & 9.8 \\
\hline
\end{tabular}

PAM, primary acquired melanosis; OSSN, ocular surface squamous neoplasia. 
Table 2. Clinicodemographic Data for 100 Patients with Pterygia

\begin{tabular}{lc}
\hline \multicolumn{1}{c}{ Variable } & Value \\
\hline Age (years) & \\
$\quad$ Mean \pm standard deviation & $50 \pm 15$ \\
$\quad$ Range & $21-83$ \\
Sex (no. of cases) & $62^{\star}$ \\
$\quad$ Male & $35^{*}$ \\
$\quad$ Female & \\
Eye (no. of cases) & 45 \\
$\quad$ Right & 55 \\
Left & \\
Location of lesion (no. of cases) & 96 \\
$\quad$ Nasal & $4^{\dagger}$ \\
Temporal & \\
Type of lesion (no. of cases) & 59 \\
$\quad$ Primary & 41 \\
Recurrent &
\end{tabular}

${ }^{*}$ Two females and one male had bilateral disease and pterygium surgery on separate occasions.

${ }^{+}$All temporal pterygia were recurrent.

These cell clusters may provide the first histological evidence supporting the view that pterygium is a disease of stem cell origin.

\section{Materials and Methods}

\section{Patients}

Patients undergoing routine pterygium excision surgery by a single surgeon (M.T.C.) were recruited from Prince of Wales Hospital, Randwick, Sydney, Australia, and from the surgeon's private practice. Clinicodemographic features recorded included patient age and sex and location (nasal or temporal) and type of lesion (primary or recurrent) (Table 2). The study population was of mixed ethnic background, but the majority of patients were of European continental origin. Patients underwent routine ophthalmic examination and documentation of the pterygium, including anterior segment photography (iPIX camera; Designs For Vision, Ronkonkoma, NY) and in vivo confocal microscopy (HRT 3 Rostock cornea module; Heidelberg Engineering, Heidelberg, Germany). There were no clinical signs of dysplasia in any of the patients, although one patient demonstrated obvious pigmentation in the head of his pterygium. All patients underwent pterygium excision with reconstruction of the resulting wound using an autologous free limbal-conjunctival graft. ${ }^{35}$ Informed consent was obtained from each patient before tissue and data collection. This study was approved by the institutional Human Research Ethics Committee and adheres to the tenets of the Declaration of Helsinki.

\section{Histopathological Evaluation}

Pterygia $(n=100)$ were FFPE and oriented such that sections were cut longitudinally through the head and the body of the pterygium (Figure 1D). Sections ( $4 \mu \mathrm{m})$ were stained with $\mathrm{H} \& \mathrm{E}$, then evaluated by two experienced senior ocular scientists (J.C. and N.D.). Unusual, suspect, and atypical cases were reviewed by a pathologist (R.C.) to provide a histopathological diagnosis.

\section{Immunohistochemistry}

Pterygia with atypical features were investigated further by immunohistochemistry. Tissues were stained with putative markers for melanocytes, LSCs, or cytokeratins (Table 3). Briefly, 4- $\mu \mathrm{m}$ paraffin sections were dewaxed in xylene and rehydrated through a graded series of ethanol baths. Sections were subjected to antigen retrieval by heating in a microwave oven in $0.1 \mathrm{~mol} / \mathrm{L} \mathrm{so-}$ dium citrate buffer ( $\mathrm{pH}$ 6.0), followed by incubation in $3 \%$ $\mathrm{H}_{2} \mathrm{O}_{2}$ in methanol to block endogenous peroxidase activity. After blocking in $20 \%$ normal goat serum in Trisbuffered saline $(\mathrm{pH} \mathrm{7.6)}$ for 30 minutes, sections were incubated overnight in primary antibody (Table 3 ) at $4^{\circ} \mathrm{C}$. Tissues were next incubated in biotinylated goat antirabbit or goat anti-mouse IgG (1:200 dilution; Dako, Glostrup, Denmark) for 30 minutes, followed by streptavidin-conjugated horseradish peroxidase (1:100 dilution; Dako) for 1 hour at room temperature. Sections were thoroughly washed with Tris-buffered saline between each step. Immunoreactivity was visualized using 3-amino-9-ethylcarbazole (AEC; Sigma-Aldrich, St. Louis, MO), and nuclei were counterstained with Mayer's hematoxylin

Table 3. Primary Antibodies Used for Immunohistochemistry

\begin{tabular}{|c|c|c|c|c|c|c|}
\hline Targeted epitope & Antibody type & Host $^{*}$ & Clone & Manufacturer $^{\dagger}$ & Catalog no. & Dilution \\
\hline Human melanosome & $\lg _{1}, \kappa$ & M & HMB-45 & DAKO & M0634 & $1: 50$ \\
\hline Melan A & $\operatorname{lgG}_{1}, \kappa$ & M & A103 & DAKO & M7196 & $1: 100$ \\
\hline S100B & $\lg G$ & $\mathrm{R}$ & - & DAKO & Z0311 & $1: 900$ \\
\hline P63 (pan) & $\operatorname{lgG}_{2 a}$ & $M$ & $4 \mathrm{~A} 4$ & DAKO & M7247 & $1: 50$ \\
\hline P63-alpha & $\lg G$ & $\mathrm{R}$ & - & CST & 4892 & $1: 20$ \\
\hline Keratin-15 & $\lg _{2 a}$ & M & MS-1068 & TFS & LHK15 & $1: 150$ \\
\hline Keratin-19 & $\operatorname{lgG}_{1}$ & M & $4 \mathrm{~A} 36$ & USB & C9097-24B & $1: 150$ \\
\hline $\mathrm{Ki}-67$ & $\lg G$ & $\mathrm{R}$ & - & TFS & RB-1510R7 & $1: 200$ \\
\hline Connexin 43 & $\operatorname{lgG}_{1}, \kappa$ & M & $\mathrm{CX}-1 \mathrm{~B} 1$ & Zymed & $13-8300$ & $1: 100$ \\
\hline Isotype & $\operatorname{lgG}_{1}$ & $M$ & - & DAKO & X0931 & $1: 100$ \\
\hline Isotype & $\lg G$ & $\mathrm{R}$ & - & DAKO & X0903 & $1: 900$ \\
\hline
\end{tabular}

${ }^{*} \mathrm{M}$, mouse; $\mathrm{R}$, rabbit.

†DAKO, DakoCytomation; CST, Cell Signaling Technology; TFS, Thermo Fisher Scientific; USB, United States Biological; Zymed, Zymed Laboratories. 
(Dako). Sections were mounted in aqueous mounting medium (Crystal Mount; Biomeda Corporation, Foster City, CA), then coverslipped in DPX mounting medium (VWR International, Poole, UK). For double-labeling, tissues were incubated in a mixture of primary antibodies (Table 3), followed by incubations in goat antimouse ${ }^{\text {Alexa488 }}$ and goat anti-rabbit ${ }^{\text {Alexa594 }}$ (Invitrogen, Carlsbad, CA) and counterstained with DAPI $(0.3 \mu \mathrm{mol} / \mathrm{L}$ final). Sections were coverslipped in Vectashield antifade mounting medium (Vector Laboratories, Burlingame, CA), then imaged. Negative control reactions included tissues that were incubated with an isotype antibody instead of an epitope-specific primary antibody. Photomicrographs were taken with a DP70 digital camera system mounted on an Olympus BX51 microscope
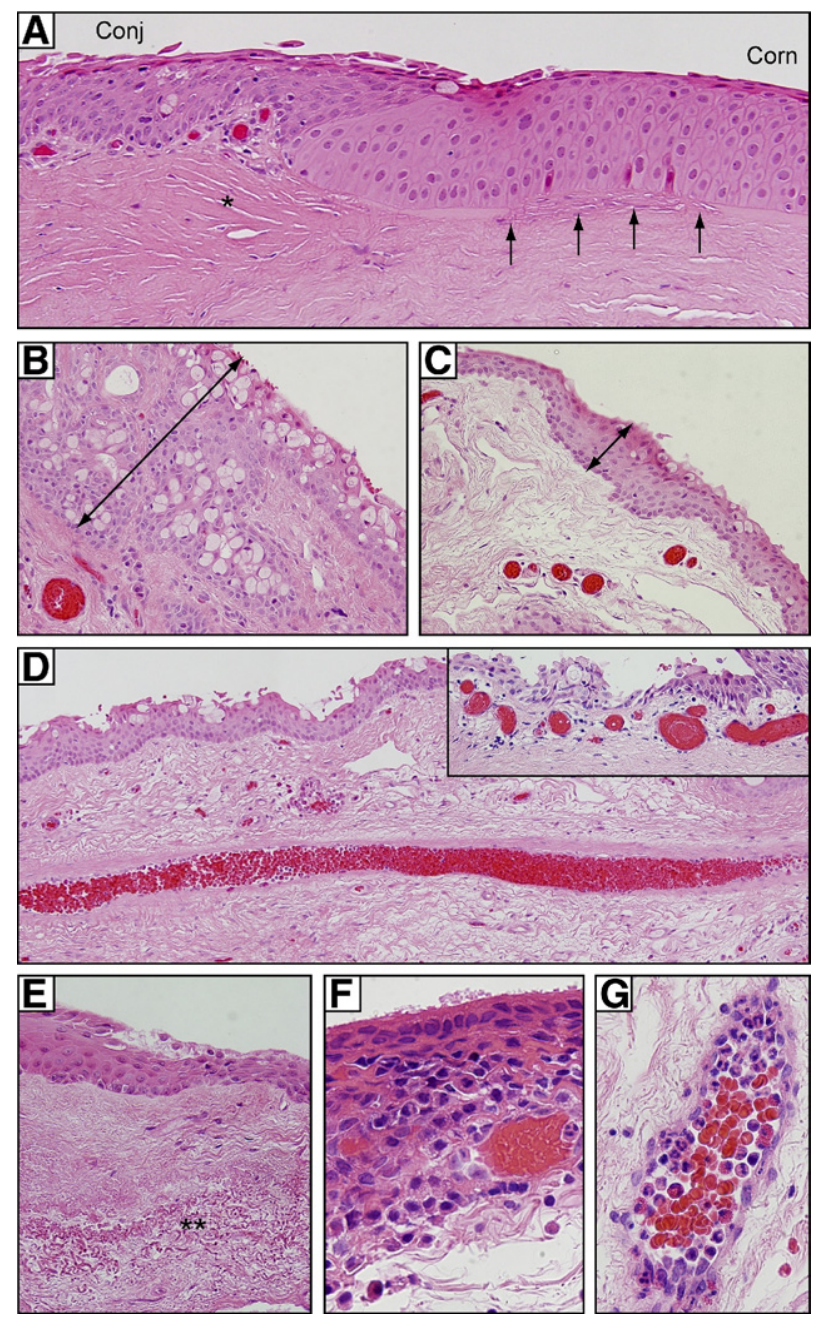

Figure 2. Typical histological features of pterygia. A: In the advancing head of a pterygium, conjunctival-like epithelium (Conj) merges abruptly into corneal epithelium (Corn). The underlying Bowman's layer (arrows) is fragmented and precedes a fibrovascular stroma (asterisk). B, C: Goblet cell hyperplasia is apparent in pterygium (B), compared with donor-matched conjunctiva (C). Note the thickness of the epithelial layer (double-headed arrows in $\mathbf{B}$ and C). D: Prominent central feeder vessel; inset shows dilated subepithelial vessels. E: Elastotic changes (double asterisk) in pterygium stroma. F: Inflammatory infiltrates in the epithelium. G: Stromal vessels loaded with polymorphonuclear leukocytes. All sections were stained with H\&E. Original magnification: $\times 200(\mathbf{A}$ and $\mathbf{D}) ; \times 400(\mathbf{B}, \mathbf{C}, \mathbf{D}$ inset, and $\mathbf{E})$ $\times 1000$ oil emersion $(\mathbf{F}$ and $\mathbf{G})$.
Table 4. Histological Findings in 100 Cases of Pterygia

\begin{tabular}{lccc}
\hline & \multicolumn{3}{c}{ Pterygia (no.) } \\
\cline { 2 - 4 } \multicolumn{1}{c}{ Histological findings } & $\begin{array}{c}\text { Primary } \\
(n=59)\end{array}$ & $\begin{array}{c}\text { Recurrent } \\
(n=41)\end{array}$ & Total \\
\hline PAM without atypia & 4 & 1 & 5 \\
PAM with atypia with a & 1 & 0 & 1 \\
$\quad$ subconjunctival nevus & & 1 & 1 \\
Epidermolysis bullosa nevus & 0 & 2 & 5 \\
OSSN & 3 & 1 & 1 \\
Dermoid-like lesion & 0 & 2 & 6 \\
Plaques & 4 & 10 & 18 \\
Basal stem cell-like clusters & 8 & \\
\hline
\end{tabular}

PAM, primary acquired melanosis; OSSN, ocular surface squamous neoplasia.

(Olympus; Sydney, Australia) and processed with Photoshop version 9 (Adobe Systems, San Jose, CA).

\section{Results}

\section{Typical and Common Histopathological Findings in Pterygia}

Common histological features observed included a proliferative and locally invasive front of pterygium epithelium that abruptly transitioned into corneal epithelium at the advancing edge (Figure 2A). At the junction between the pterygium epithelium and normal cornea, the stroma was often characterized by feeder blood vessels (Figure $2 \mathrm{~A}$, asterisk) that preceded the fibroblastic stroma. The advancing pterygium edge was demarcated by a fragmented Bowman's layer (Figure 2A, arrows). Goblet cell hyperplasia was prominent in pterygium epithelium (Figure 2B), compared with autologous normal conjunctiva (Figure $2 \mathrm{C}$ ). Feeder vessels extending the length of the lesion were regularly noted (Figure 2D), as well as sub-
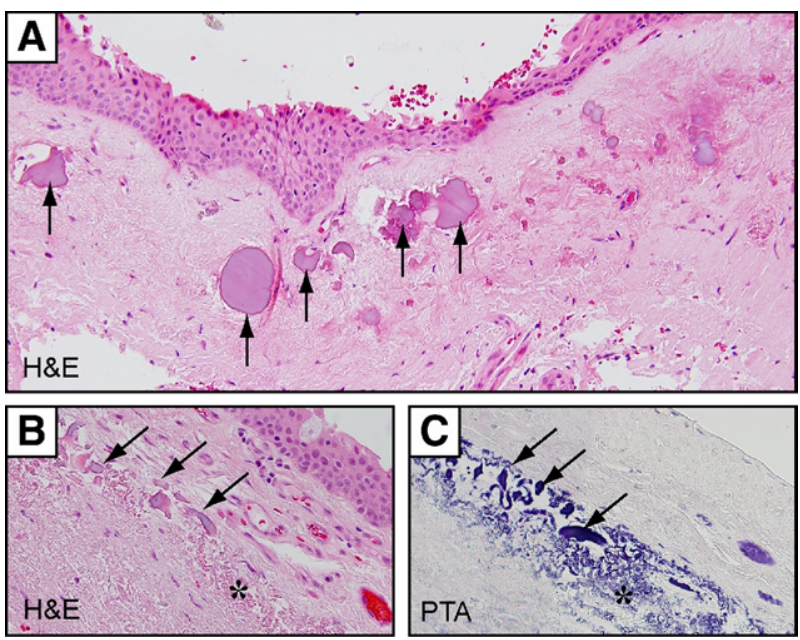

Figure 3. Stromal plaques in pterygia stained with H\&E (A and B) or phosphotungstic acid (PTA) (C). Irregular-shaped stromal plaques (arrows) with an amorphous appearance were frequently associated with elastotic changes (asterisk). Plaques appear lilac in H\&E-stained sections and deep blue in PTA-stained sections. Elastin fibers also stained blue with PTA. Original magnification: $\times 200(\mathbf{A}) ; \times 600(\mathbf{B}$ and $\mathbf{C})$. 
epithelial neovascularization (Figure 2D, inset). Stromal elastosis (Figure 2E, double asterisk) and both intra- and subepithelial (Figure 2F) and intravascular inflammation were present in $60 \%$ of cases.

\section{Uncommon and Novel Histopathological Findings in Pterygia}

Uncommon histological features included basophilic stromal plaques within the pterygium body in $6 \%$ of cases (Table 4) that localized to elastotic zones (Figure 3 , arrows). These plaques varied in size and shape, and were generally lilac in color after H\&E staining (Figure 3, A and B, arrows) or dark blue when stained with phosphotungstic acid (Figure 3C, asterisk). However, we could not identify their composition further with other histological stains, including tetrachrome, Safranin O, von Kossa stain, or alizarin crimson (data not shown).

Small clusters of basal cells were observed in $18 \%$ of our pterygium specimens. Cells within these aggregates were smaller, had increased nuclear-to-cytoplasm ratio, consisted of 8 to 15 cells anchored to the basement membrane, and were invariably associated with corneal- like epithelium near the head of the pterygium (Figure 4A, ovals). Morphologically, these cells appeared primitive and less differentiated than their suprabasal counterparts, suggesting that they may be stem cell like. Such observations prompted us to partially phenotype these cells by immunostaining, using well-accepted markers of LSCs. Indeed, cells within these microclusters demonstrated immunoreactivity to CK-15, CK-19, p63 (pan), and $\mathrm{p} 63 \alpha$ (Figure $4, \mathrm{C}, \mathrm{D}, \mathrm{F}$, and G, respectively) and were double-immunoreactive to CK-15/p63 $\alpha$ (Figure $4 \mathrm{H}$ ) and CK-19/p63 $\alpha$ (not shown), but lacked immunoreactivity to Ki-67 (proliferation marker) (Figure 4E) or Cx43 (gap junction protein) (data not shown). Our findings suggest that, although these cells are not proliferating (lacked Ki-67 expression), they retain proliferative potential (strong p63 $\alpha$ expression) and may become activated when appropriate signaling mechanisms are initiated during pterygium development. These cell clusters were documented by Ernst Fuchs ${ }^{36}$ more than a century ago in his seminal article "Ueber das Pterygium" at both a microscopic (Figure 4B) and macroscopic level (Figure 5A) as small spots or flecks at the head of pterygia. Commonly known as Fuchs' flecks (or Fuchs' patches, Fuchs' islets), these pterygium cell clusters
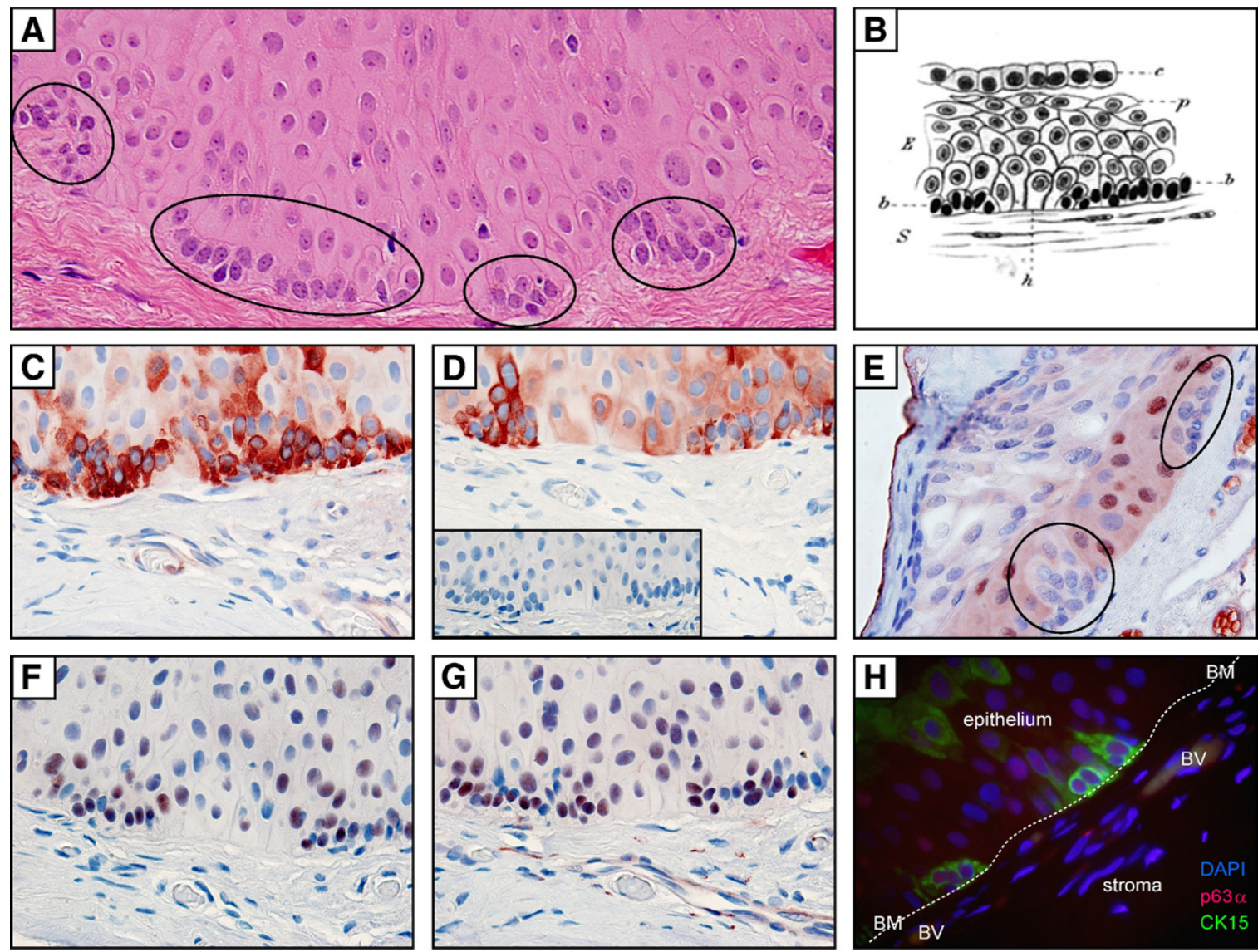

Figure 4. Stem cell microclusters in pterygium tissue. A: H\&E-stained section of a pterygium illustrating multiple mini-aggregates of basal epithelial cells (ovals). B: Pterygium epithelium as illustrated by Ernst Fuchs ${ }^{36}$ in 1892. C-G: Pterygium immunolabeled with CK-15, CK-19, Ki-67, p63 (pan), and p63 $\alpha$ (C-G, respectively), using an indirect immunoperoxidase method with 3-amino-9-ethylcarbazole chromogen; red denotes positive labeling. Staining is absent in sections incubated with control IgG (D, inset). H: Indirect immunofluorescent double-labeling of pterygium epithelial cell clusters with CK-15 (green), p63 $\alpha$ (red), and counterstained with DAPI (blue); note basement membrane (BM, indicated by dotted line) and blood vessels (BV). Original magnification, $\times 1000$ oil emersion (all photomicrographs). Image $\mathbf{B}$ is reproduced with permission from Springer (original publication: Fuchs E. Ueber der Pterygium. Graefes Archiv Ophthalmol 1892, 38:1-89). 

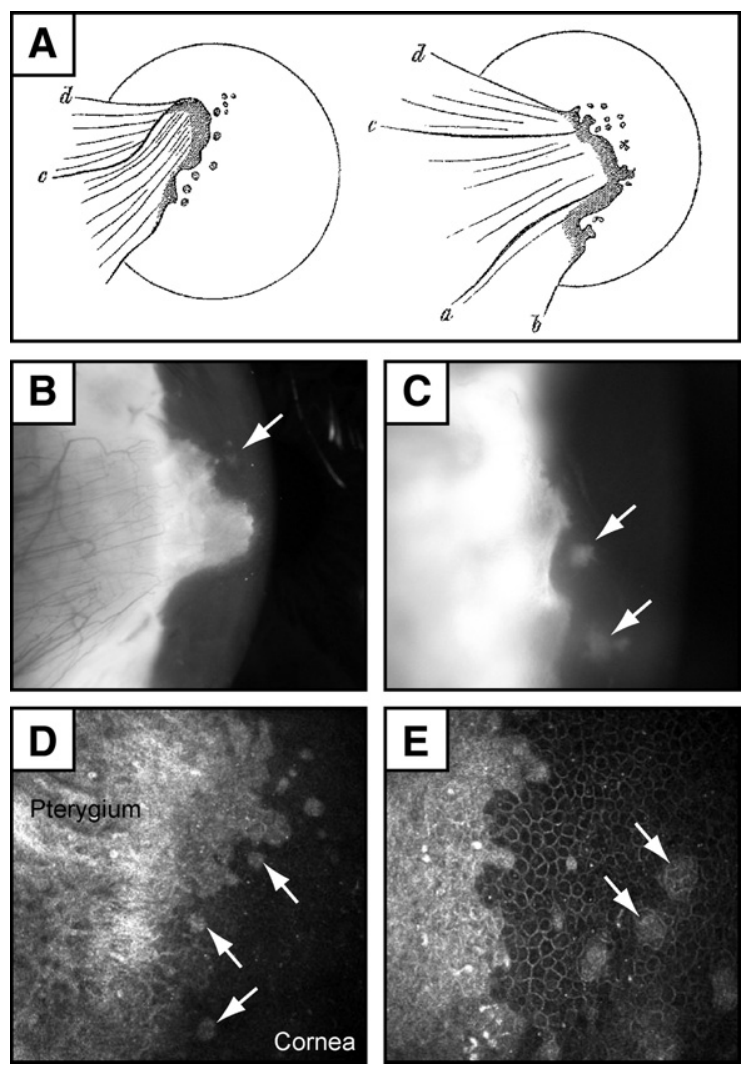

Figure 5. Clinical appearance of Fuchs' flecks in pterygia. A: Original illustrations by Ernst Fuchs ${ }^{36}$ show small spots or fleckchen in the cap region at the head of pterygia. B-E: Pterygia with Fuchs' flecks (arrows) under slit lamp (B and $\mathbf{C}$ ) and in vivo confocal microscopy (D and E). Slit lamp photographs were taken with an iPIX camera (Designs For Vision, Ronkonkoma, NY) and confocal micrographs with an HRT 3 Rostock cornea module (Heidelberg Engineering, Heidelberg, Germany). Confocal images were taken with a $63 \times$ objective. The field of view is $400 \mu \mathrm{m} \times 400 \mu \mathrm{m}$ for (D) and $300 \mu \mathrm{m} \times 300 \mu \mathrm{m}$ for $(\mathbf{E})$. Image $\mathbf{A}$ is reproduced with permission from Springer (original publication: Fuchs E. Ueber der Pterygium. Graefes Archiv Ophthalmol 1892, 38:1-89).

could be visualized in our patients by slit-lamp examination (Figure 5, B and C) and by confocal microscopy (Figure 5, D and E).

\section{Atypical Histopathological Findings in Pterygia}

Atypical epithelial and melanocytic lesions were identified in $12 \%$ of pterygia (Figure 6 and Table 4). Rete ridge-like down-growths were occasionally noted in the hyperplastic epithelium (Figure 6A). Foci of epithelial dysplasia ranging from mild to moderate to severe (Figure 6, B, C, and D, respectively) were observed in pterygium epithelium, where cells displayed increased nuclear-to-cytoplasmic ratio and loss of polarity affecting the basal (Figure 6B), the suprabasal (Figure 6C), or the entire epithelium (Figure 6D). Nonetheless, the metastatic potential of these lesions is low, given that they do not breach the basement membrane (Figure 6, A-D).

Melanocytic lesions were identified in $7 \%$ of our samples, which included racial pigmentation (7\%) (Figure $6 \mathrm{E})$, primary acquired melanosis (PAM) without (5\%) and with atypia (1\%) (Figure 6, F and $\mathrm{G}$, respectively), and two cases of conjunctival nevi (Figure $6, \mathrm{H}-\mathrm{J}$ ). One nevus extended from the pterygium body into the corneal stroma, with well-circumscribed nonpigmented melanocytic nests found at the surgical margin (Figure 6, I and $\mathrm{H})$. Nonpigmented nevi may be difficult to detect clinically, especially if masked by an inflamed pterygium. CK-19 staining was therefore used to demarcate pterygium epithelium, distinct from the underlying symmetrical nevus (Figure 7A). Under higher magnification, CK19-negative melanocytes were identified as uniform, rounded, occasionally displaying hyperchromatic nuclei, and generally confined to cohesive epithelioid nevocytic
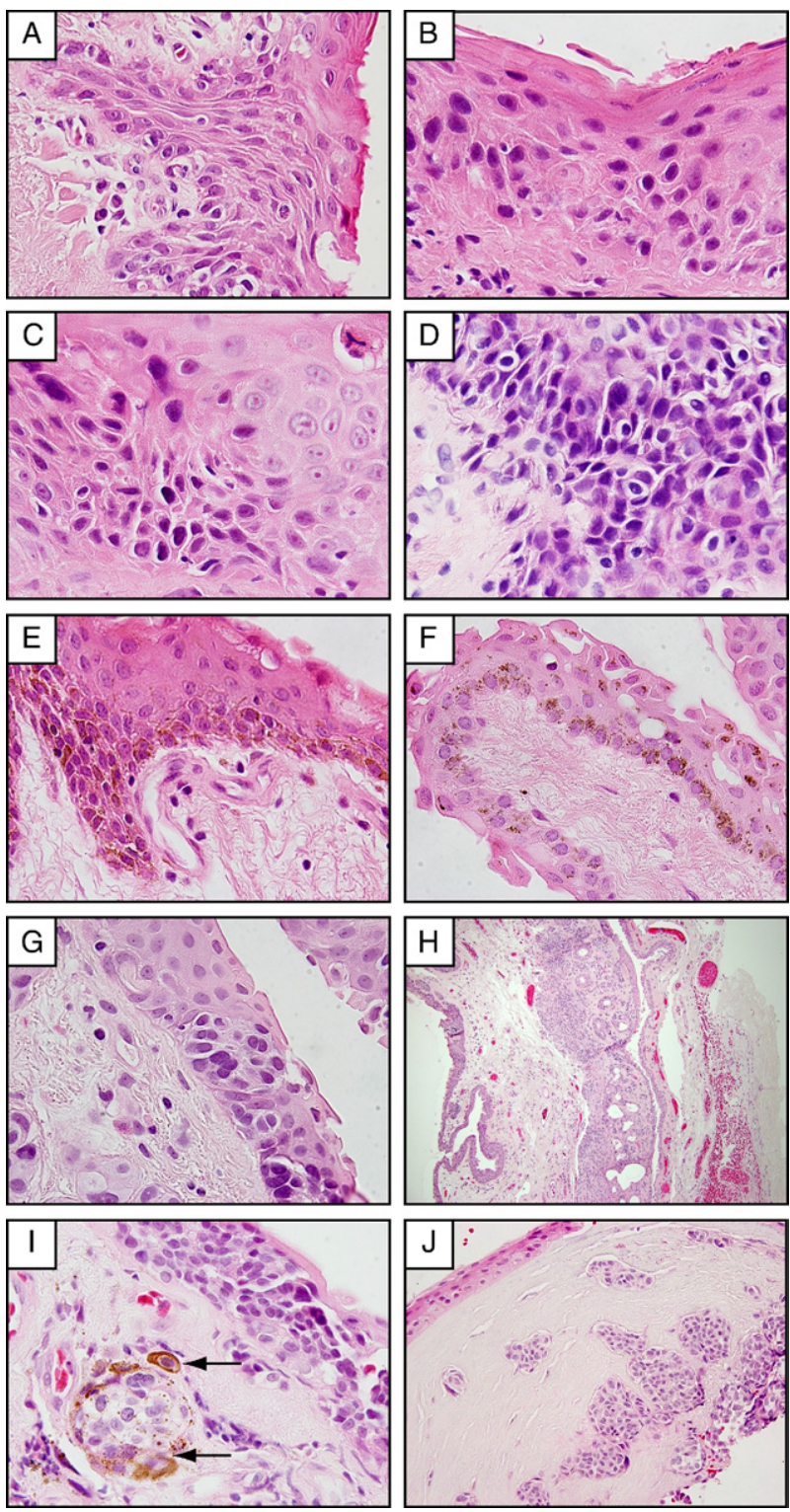

Figure 6. Atypical histological features in pterygia included pterygium epithelium demonstrating papillary folding (A) and dysplastic changes ranging from mild (B) to moderate $(\mathbf{C})$ to severe $(\mathbf{D})$. Melanocytic lesions included racial pigmentation (note layers of pigmented basal melanocytes) (E), PAM without atypia (F), PAM with atypia (G), subconjunctival nonpigmented compound nevus (H), and a nonpigmented nevus (I) from a patient with epidermolysis bullosa that invaded the corneal stroma (J). Arrows in I point to melanophages that have acquied pigmented granules and surround a melanocytic nest. Sections were assessed after H\&E staining. Original magnification: $\times 1000$ oil emersion $(\mathbf{A}-\mathbf{G}$ and $\mathbf{I}) ; \times 100$ $(\mathbf{H}) ; \times 400(\mathbf{J})$ 

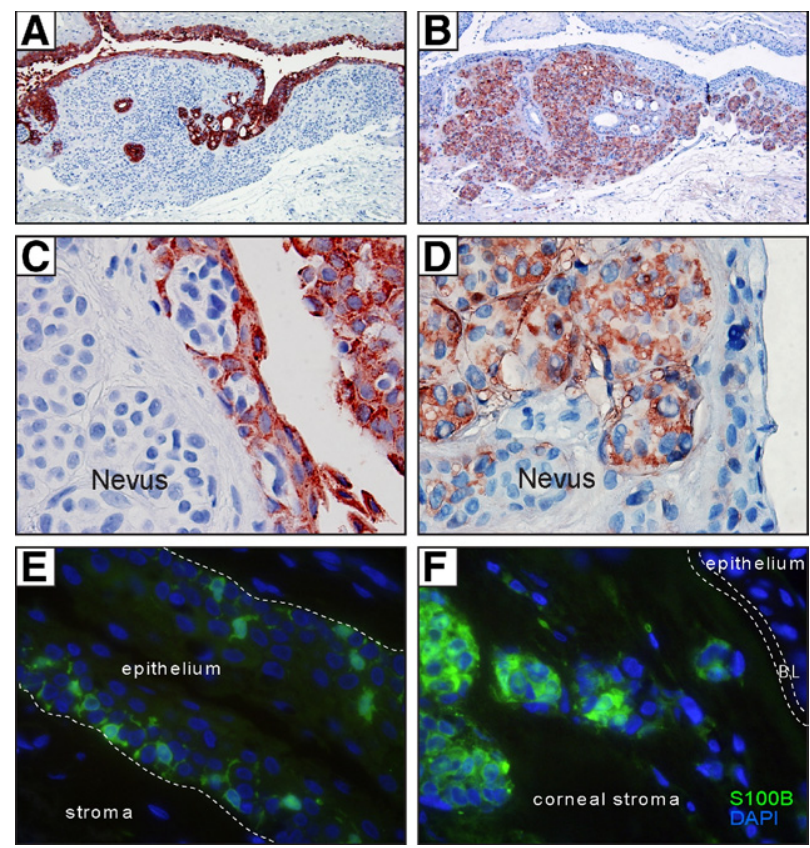

Figure 7. Cytokeratin and S100B staining of nevi in pterygia. Indirect immunoperoxidase (A-D) and immunofluorescence ( $\mathbf{E}$ and $\mathbf{F})$ techniques demonstrate CK-19 immunoreactivity in pterygium epithelium (A and C) or S100B immunoreactivity in nevus melanocytes $(\mathbf{B}, \mathbf{D}$, and $\mathbf{F})$ and in dendritiform cells scattered within the epithelium $(\mathbf{E})$. In panels $\mathbf{A}-\mathbf{D}$, positive labeling is denoted by red color (from 3-amino-9-ethylcarbazole chromogen) and nuclei counterstaining in blue (hematoxylin). In panels $\mathbf{E}$ and $\mathbf{F}, \mathrm{S} 100 \mathrm{~B}$ expression is denoted by green immunofluorescence and DAPI counterstaining in blue. In $\mathbf{E}$, the hatched line indicates the pterygium basement membrane; in $\mathbf{F}$, it indicates Bowman's layer (BL). Original magnification: $\times 100(\mathbf{A}$ and $\mathbf{B})$; $\times 1000$ oil emersion $(\mathbf{C}-\mathbf{F})$.

nests without pagetoid spread (Figure 7C). When samples were labeled with melanocytic marker S100B, stromal-epithelial junctional involvement became more obvious (Figure 7, B and D). Similar staining patterns were observed with other melanocytic markers, such as melan A and HMB-45 (data not shown). S100B-positive cells were also detected within the pterygium epithelium; however, in contrast to the epithelioid melanocytes within the nevus, these intraepithelial cells were dendritiform in morphology (Figure 7E). The second nevus displayed cell invasion of the epithelium (pagetoid spread; not shown) with prominent and lateral nonpigmented melanocytic spread. This specimen, although diagnosed as a benign lesion, was viewed as a suspect invasive melanoma, because of the spread of S100B-positive melanocytic nests from the main disease foci within the conjunctiva into the corneal stroma (Figure 7F).

Last, we identified cutaneous features within a recurrent pterygium from a 67-year-old man (Figure 8). This unusual wing-shaped lesion had the macroscopic appearance of a typical pterygium, except that hairs were visibly growing out of the body (Figure 8A). On microscopy, we observed a nonkeratinizing squamous epithelium with goblet cells adjacent to well-differentiated cutaneous elements such as hair follicles and sebaceous and sweat glands (Figure 8, B-D). These features are reminiscent of limbal dermoids, ${ }^{37}$ but this patient had no history of such lesions before he developed a pterygium.

\section{Discussion}

By standardizing the orientation of our specimens (Figure 1D), we identified several previously documented common, uncommon, and novel histopathological features in pterygia. Common findings included a prominent migratory front of actively proliferating and locally invasive epithelium with evidence of Bowman's layer dissolution (Figure 2), which we have previously shown to be mediated by the activity of UV-induced matrix metalloproteinase. . $^{3,6}$ Other features included a reactive fibrovascular stroma with evidence of epithelial-mesenchymal transition, ${ }^{38}$ elastosis, and intravascular, subepithelial, and intraepithelial leukocyte infiltration (Figure 2), likely mediated through UV-induced cytokines and growth factors. ${ }^{2,9}$ As in previous studies, leukocyte infiltrates in our pterygium specimens were neutrophils, T cells, plasma cells, macrophages, and mast cells. ${ }^{39,40}$ The stroma comprising an altered extracellular matrix has also been studied and shown to consist of excess deposits of collagens, heparin sulfates, versican, laminin, and fibronectin. ${ }^{41,42}$ In addition, we also observed foci of amorphous basophilic material in some pterygia, which were frequently associated with elastotic changes within the stroma. Plaques and associated elastotic changes appeared blue after treatment with phosphotungstic acid, suggesting that they may have a similar chemical composition (Figure 3C). Although these deposits have been documented by others, ${ }^{43,44}$ their composition and precisely how they form are still unknown. Stromal plaques have also been described in climatic droplet keratopathy, ${ }^{45}$ and it has been hypothesized that these plaques may be derived from UV-denatured plasma constituents. ${ }^{46}$ Proteomic analysis of stromal plaques found in climatic droplet keratopathy revealed that they were rich in annexin $\mathrm{A} 2$ and glyceraldehyde 3-dehydrogenase. ${ }^{47}$ We can only speculate that the stromal plaques in pterygia may be similar in composition to those reported in climatic droplet keratopathy,
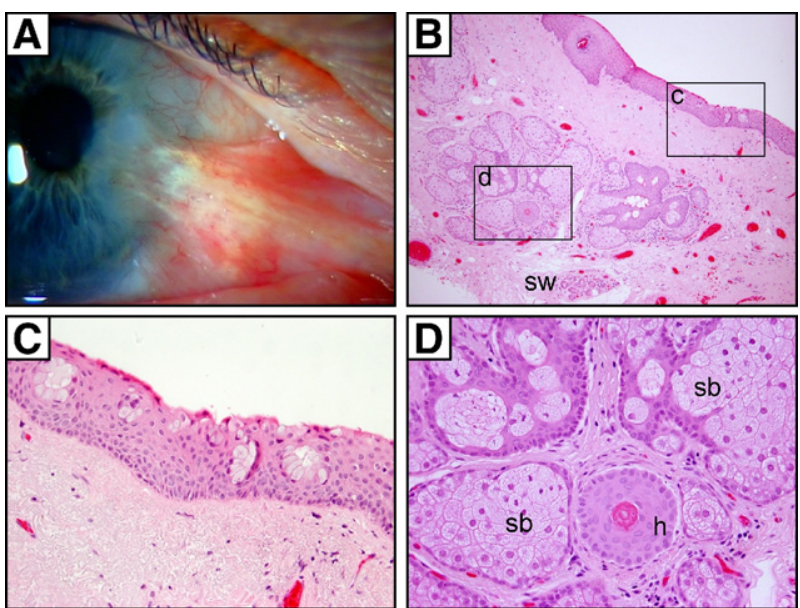

Figure 8. Cutaneous elements in a recurrent pterygium. Clinical image of a pterygium with hairs growing from the body (A) and its corresponding H\&Estained paraffin sections $(\mathbf{B}-\mathbf{D})$. The regions encompassed by the rectangles (c and d) in panel $\mathbf{B}$ are magnified in panels $\mathbf{C}$ and $\mathbf{D}$, respectively. Goblet cell clusters within the conjunctival portion of the pterygium (C) overlie cutaneous elements (D) such as sebaceous glands (sb), hair follicles (h), and sweat glands $(\mathrm{sw})$. Original magnification: $\times 100(\mathbf{B}) ; \times 400(\mathbf{C}$ and D). 
given that both diseases are strongly associated with UV exposure. ${ }^{16}$ One reason for their presence in only a proportion of specimens might be related to the stage of pterygium development and amount of cumulative UV exposure.

Controversy also surrounds the origins of the osmophilic elastoid bands within the pterygium substantia propria. Although it was originally described as actinic elastosis (elastotic degeneration of collagen) through the actions of UV radiation, because similar changes have been described in skin exposed to solar radiation, ${ }^{48}$ Austin et $\mathrm{al}^{44}$ now claim that elastodysplasia plays a role through excess production of elastin derived from UVactivated or injured fibroblasts. Evidence to support this theory was presented by Wang et $\mathrm{al}^{49}$ who detected mutations in the $3^{\prime}$-untranslated region of tropoelastin in pingueculae and UV-irradiated conjunctival fibroblasts.

The concept that pterygia arise from LSCs has been a topic of discussion for decades. In a seminal article in 1971, Davanger and Evensen ${ }^{23}$ concluded that "a failure in the limbal structure may be the cause of pterygia." Some 20 years later, Tseng et al ${ }^{26}$ speculated that pterygia represent a focal zone of LSC dysfunction (Figure 1, A and B). Our model of chronic focal UV radiation to the limbal margin ${ }^{50}$ provides an explanation for how LSCs and their niche might be damaged, and Dushku et al ${ }^{51}$ postulated that pterygia arise from altered limbal basal epithelial cells that took on a migratory phenotype.

More than a century ago, Fuchs ${ }^{36}$ identified small clusters of conjunctival-like basal cells dispersed among the corneal-like epithelium in pterygia (Figure 4B). Such islands of pterygium epithelial cells were also reported in our previous work. ${ }^{9}$ In the present study, we further characterized these small, morphologically primitive cells as resembling LSCs through their coexpression of CK-15, CK-19, and $\mathrm{p} 63 \alpha$ (Figure $4 \mathrm{H}$ ) and localized them to the advancing head of the pterygium. In location and size, they are similar to Fuchs' flecks, ${ }^{36}$ which can be visualized by slit lamp and by in vivo confocal imaging (Figure 5). Our observations support the notion that pterygium is a disease of LSCs, and the presence of these cell clusters may account for the clinical behavior of pterygium. We hypothesize that these primitive cell clusters may be activated to proliferate, forming an invasive pterygium (Figure 1A).

It is unclear why pterygium epithelial cell clusters are present in only $\sim 20 \%$ of our specimens, but we suspect that i) some may have escaped detection, because their small size makes them difficult to identify without serial sectioning, or that ii) their presence may be associated with actively growing pterygia, but it is our normal practice to resect lesions when they are quiescent. Further studies are also required to establish if pterygium epithelial cell clusters are functionally, phenotypically, or genetically altered as a result of UV radiation.

Finally, within a clinically apparent pterygium, we found cutaneous elements (hair follicles, sebaceous glands, and sweat glands) adjacent to goblet cells in pterygium epithelium (Figure 7). This unusual finding supports the notion that stem cells within the limbus might retain the capacity to differentiate into skin-like tissue. The precise mechanism for this reprogramming is unclear, but we speculate that UV radiation may be the trigger, because we have recently noted the development of cutaneous elements in corneas of UV-irradiated mice (unpublished observation). Alternatively, these cutaneous elements might have originated from the caruncle, which is known to contain hairs and sebaceous and sweat glands, as well as lacrimal glands and goblet cells. $^{52}$

Ocular surface squamous neoplasia (OSSN) is a spectrum of diseases that ranges from epithelial dysplasia to carcinoma in situ to squamous cell carcinoma. ${ }^{53,54}$ It is commonly found in elderly men with a history of chronic UV exposure. ${ }^{55}$ Increased incidence of OSSN has also been reported in HIV-positive individuals, with OSSN showing a female predominance and sometimes presenting at a younger age ${ }^{56,57} \mathrm{As}$ with pterygia, UV exposure is thought to contribute to the pathogenesis of OSSN. ${ }^{55,58}$ We observed mild to severe epithelial dysplasia in $5 \%$ of our pterygia, but no carcinoma in situ or squamous cell carcinoma. This is in contrast to studies from Malawi and South Africa, ${ }^{17,31}$ where $>29 \%$ of pterygia had concurrent OSSN (Table 1), leading to suggestions that tumors may arise from preexisting lesions (such as pterygia). Recently, Hirst et al ${ }^{32}$ noted the full spectrum of OSSN in $\sim 10 \%$ of their pterygia from Brisbane, Australia (approximately double the rate of our Sydney cohort). One possible explanation for this disparity within an Australian population is greater UV exposure in Brisbane, compared with Sydney, because Brisbane is closer to the equator (latitude $27^{\circ} 28^{\prime} \mathrm{S}$ versus $33^{\circ} 51^{\prime} \mathrm{S}$ ). Increased UV exposure may also explain higher OSSN rates in pterygia in African populations, but racial factors (continental origin) and concurrent HIV infections might also play a role. The relationship between pterygia and neoplasms is not completely understood, but UV-induced mutations in tumor suppressor genes may play a role. ${ }^{19}$ The tumor suppressor protein p53 is responsible for regulating cell-cycle arrest ${ }^{59}$ and is hypothesized to be mutated in pterygia, based on its overexpression in pterygium tissues. ${ }^{60-62}$ In OSSN, p53 is similarly overexpressed, ${ }^{63}$ and signature UVinduced mutations (CC to TT transitions) have been detected in these lesions. ${ }^{64}$ Whether p53 mutations are present within our newly identified pterygium cell clusters remains to be investigated. In one study, no TP53 mutations were observed in pterygium specimens after laser-capture microdissection of the entire epithelium. ${ }^{65}$

Primary acquired melanosis of the conjunctiva is a clinical classification of melanocytic lesions that falls between nevus and invasive melanoma. PAM occurs predominantly in middle-aged persons of European continental origin, but can be present in patients as young as 15 years of age. ${ }^{66}$ PAM is further grouped into lesions with and without cytological atypia, and it may account for $11 \%$ of all conjunctival tumors. ${ }^{67,68}$ Histological grading of PAM is important in its management, because PAM with atypia progresses to melanoma, ${ }^{66}$ and lesions with epithelioid features have been associated 
with invasion and metastasis, ${ }^{68}$ but PAM without atypia do not progress to melanoma. ${ }^{66}$ In the present series of 100 pterygia, we observed seven cases of racial pigmentation, six cases of PAM (with and without atypia), and two cases of nevi (one patient had a history of cutaneous melanoma; the other had epidermolysis bullosa). These frequencies are comparable to those in a study by Perra et $\mathrm{al}^{33}$ who reported seven cases of PAM and two cases of nevi in a series of 80 pterygia. These numbers, although small, are of concern for the ophthalmologist, because PAM with atypia is considered a premalignant condition and $13 \%$ to $50 \%$ of PAM cases may progress to melanoma, ${ }^{66,69}$ a potentially fatal disease if undetected. Shields et $\mathrm{al}^{67}$ reported that $13 \%$ of patients with PAM had bilateral disease. In PAM with atypia, the mean interval for melanoma development is 39 months. ${ }^{66}$ Therefore, close monitoring by clinicians with longer follow-up periods are required in patients with pterygia in which PAM with atypia has been identified.

Amelanotic melanoma and PAM of the conjunctiva are rare, but cases have been reported. ${ }^{70,71}$ The nevi in our case series were not pigmented. These lesions are clinically and histologically difficult to diagnose. Immunohistochemical markers such as S100B, HMB45, and melan A may help identify and differentiate between benign and malignant melanocytic lesions. In particular, HMB-45-positive staining is reported to be associated with atypia and is recommended for differentiating between PAM with and without atypia. ${ }^{72,73}$ The Wilms tumor gene ${ }^{74}$ and Ki-67 staining ${ }^{73}$ may be used to distinguish between benign and malignant nevi. In our series, all melanocytes labeled intensely with $\mathrm{S100B}$, whereas the other melanocytic markers, HMB-45 and melan A, had a similar distribution but with less intense staining. The nevus associated with epidermolysis bullosa was faintly immunoreactive to HMB-45, but did not stain for Ki-67 (data not shown), suggesting that it might be a benign nevus. Nonetheless, long-term follow-up is required given its location at the surgical margin within the corneal stroma.

In summary, we have provided evidence that pterygium is a disease of stem cells in which clusters of pterygium epithelial cells expressing putative limbal stem cell markers correspond to Fuchs' flecks at the head of the pterygium. Our study also showed that preneoplastic diseases (such as PAM with atypia and OSSN) may coexist with pterygia, and we speculate that cumulative genetic damage from chronic UV exposure may be a shared etiology between these conditions. These preneoplastic conditions could remain undiagnosed if the excised pterygium is discarded, and we recommend that all pterygia be subjected to thorough histological evaluation. Incomplete excision of PAM with atypia or OSSN is of concern, given the potential for transformation and recurrence. ${ }^{66,75}$ In such cases, use of topical chemotherapeutic agents, ${ }^{76}$ such as interferon $\alpha-2 b$ alone ${ }^{77}$ or in combination with retinoic acid, ${ }^{78}$ is proving to be highly efficacious and may be useful in the treatment of residual disease. Annual follow-up for the remainder of the patient's life is advisable. ${ }^{66,75}$

\section{References}

1. Duke-Elder S (Ed): Diseases of the Outer Eye Part 1. System of Ophthalmology 8. London: Kimpton, 1965, pp 569-585

2. Di Girolamo N, Chui J, Coroneo MT, Wakefield D: Pathogenesis of pterygia: role of cytokines, growth factors, and matrix metalloproteinases. Prog Retin Eye Res 2004, 23:195-228

3. Di Girolamo N, McCluskey P, Lloyd A, Coroneo MT, Wakefield D: Expression of MMPs and TIMPs in human pterygia and cultured pterygium epithelial cells. Invest Ophthalmol Vis Sci 2000, 41:671679

4. Di Girolamo N, Coroneo MT, Wakefield D: Active matrilysin (MMP-7) in human pterygia: potential role in angiogenesis. Invest Ophthalmol Vis Sci 2001, 42:1963-1968

5. Di Girolamo N, Kumar RK, Coroneo MT, Wakefield D: UVB-mediated induction of interleukin-6 and -8 in pterygia and cultured human pterygium epithelial cells. Invest Ophthalmol Vis Sci 2002, 43:34303437

6. Di Girolamo N, Coroneo MT, Wakefield D: UVB-elicited induction of MMP-1 expression in human ocular surface epithelial cells is mediated through the ERK1/2 MAPK-dependent pathway. Invest Ophthalmol Vis Sci 2003, 44:4705-4714

7. Di Girolamo N, Coroneo M, Wakefield D: Epidermal growth factor receptor signaling is partially responsible for the increased matrix metalloproteinase-1 expression in ocular epithelial cells after UVB radiation. Am J Pathol 2005, 167:489-503

8. Di Girolamo N, Wakefield D, Coroneo MT: UVB-mediated induction of cytokines and growth factors in pterygium epithelial cells involves cell surface receptors and intracellular signaling. Invest Ophthalmol Vis Sci 2006, 47:2430-2437

9. Chui J, Di Girolamo N, Wakefield D, Coroneo MT: The pathogenesis of pterygium: current concepts and their therapeutic implications. Ocul Surf 2008, 6:24-43

10. Kobayashi H, Kohshima S: Unique morphology of the human eye. Nature 1997, 387:767-768

11. Moran DJ, Hollows FC: Pterygium and ultraviolet radiation: a positive correlation. Br J Ophthalmol 1984, 68:343-346

12. Threlfall TJ, English DR: Sun exposure and pterygium of the eye: a dose-response curve. Am J Ophthalmol 1999, 128:280-287

13. McCarty CA, Fu CL, Taylor HR: Epidemiology of pterygium in Victoria, Australia. Br J Ophthalmol 2000, 84:289-292

14. Tan CS, Lim TH, Koh WP, Liew GC, Hoh ST, Tan CC, Au Eong KG Epidemiology of pterygium on a tropical island in the Riau Archipelago. Eye 2006, 20:908-912

15. Lim R, Mitchell P, Cumming RG: Cataract associations with pinguecula and pterygium: the Blue Mountains Eye Study. Am J Ophthalmol 1998, 126:717-719

16. Taylor HR, West SK, Rosenthal FS, Munoz B, Newland HS, Emmett EA: Corneal changes associated with chronic UV irradiation. Arch Ophthalmol 1989, 107:1481-1484

17. Clear AS, Chirambo MC, Hutt MS: Solar keratosis, pterygium, and squamous cell carcinoma of the conjunctiva in Malawi. Br J Ophthalmol 1979, 63:102-109

18. Kerkenezov N: A pterygium survey of the far north coast of New South Wales. Trans Ophthalmol Soc Aust 1956, 16:110-119

19. Di Girolamo N: Signalling pathways activated by ultraviolet radiation: role in ocular and cutaneous health. Curr Pharm Des 2010, 16:13581375

20. Coroneo MT, Muller-Stolzenburg NW, Ho A: Peripheral light focusing by the anterior eye and the ophthalmohelioses. Ophthalmic Surg 1991, 22:705-711

21. Di Girolamo N, Bosch M, Zamora K, Coroneo MT, Wakefield D, Watson SL: A contact lens-based technique for expansion and transplantation of autologous epithelial progenitors for ocular surface reconstruction. Transplantation 2009, 87:1571-1578

22. Figueira EC, Di Girolamo N, Coroneo MT, Wakefield D: The phenotype of limbal epithelial stem cells. Invest Ophthalmol Vis Sci 2007, 48:144-156

23. Davanger $M$, Evensen A: Role of the pericorneal papillary structure in renewal of corneal epithelium. Nature 1971, 229:560-561

24. Goldberg MF, Bron AJ: Limbal palisades of Vogt. Trans Am Ophthalmol Soc 1982, 80:155-171 
25. Shortt AJ, Secker GA, Munro PM, Khaw PT, Tuft SJ, Daniels JT: Characterization of the limbal epithelial stem cell niche: novel imaging techniques permit in vivo observation and targeted biopsy of limba epithelial stem cells. Stem Cells 2007, 25:1402-1409

26. Tseng SCG, Chen JJY, Huang AJW, Kruse FE, Maskin SL, Tsai RJF Classification of conjunctival surgeries for corneal diseases based on stem cell concept. Ophthalmol Clin North Am 1990, 3:595-610

27. Huang AJ, Tseng SC: Corneal epithelial wound healing in the absence of limbal epithelium. Invest Ophthalmol Vis Sci 1991, 32:96-105

28. Mourits MP, Wyrdeman HK, Jurgenliemk-Schulz IM, Bidlot E: Favorable long-term results of primary pterygium removal by bare sclera extirpation followed by a single 90Strontium application. Eur J Ophthalmol 2008, 18:327-331

29. Hirst LW: The treatment of pterygium. Surv Ophthalmol 2003, 48:145180

30. Ang LP, Chua JL, Tan DT: Current concepts and techniques in pterygium treatment. Curr Opin Ophthalmol 2007, 18:308-313

31. Sevel D, Sealy R: Pterygia and carcinoma of the conjunctiva. Trans Ophthalmol Soc UK 1969, 88:567-578

32. Hirst LW, Axelsen RA, Schwab I: Pterygium and associated ocular surface squamous neoplasia. Arch Ophthalmol 2009, 127:31-32

33. Perra MT, Colombari R, Maxia C, Zucca I, Piras F, Corbu A, Bravo S, Scarpa A, Sirigu P: Finding of conjunctival melanocytic pigmented lesions within pterygium. Histopathology 2006, 48:387-393

34. Erie JC, Campbell RJ, Liesegang TJ: Conjunctival and corneal intraepithelial and invasive neoplasia. Ophthalmology 1986, 93:176-183

35. Coroneo MT: Beheading the pterygium. Ophthalmic Surg 1992, 23 : 691-692

36. Fuchs E: Ueber das Pterygium [Concerning the pterygium]. German. Graefes Arch Ophthalmol 1892, 38:1-89

37. Garner A: The pathology of tumours at the limbus. Eye (Lond) 1989 , 3:210-217

38. Kato N, Shimmura S, Kawakita T, Miyashita H, Ogawa Y, Yoshida S, Higa K, Okano H, Tsubota K: Beta-catenin activation and epithelialmesenchymal transition in the pathogenesis of pterygium. Invest Ophthalmol Vis Sci 2007, 48:1511-1517

39. Perra MT, Maxia C, Zucca I, Piras F, Sirigu P: Immunohistochemical study of human pterygium. Histol Histopathol 2002, 17:139-149

40. Ribatti D, Nico B, Maxia C, Longo V, Murtas D, Mangieri D, Perra MT, De Giorgis M, Piras F, Crivellato E, Sirigu P: Neovascularization and mast cells with tryptase activity increase simultaneously in human pterygium. J Cell Mol Med 2007, 11:585-589

41. John-Aryankalayil M, Dushku N, Jaworski CJ, Cox CA, Schultz G, Smith JA, Ramsey KE, Stephan DA, Freedman KA, Reid TW, Carper DA: Microarray and protein analysis of human pterygium. Mol Vis 2006, 12:55-64

42. Naib-Majani W, Eltohami I, Wernert N, Watts W, Tschesche H, Pleyer $U$, Breipohl W: Distribution of extracellular matrix proteins in pterygia: an immunohistochemical study. Graefes Arch Clin Exp Ophthalmol 2004, 242:332-338

43. Vojniković B, Njirić S, Zamolo G, Toth I, Apanjol J, Coklo M: Histopathology of the pterygium in population on Croatian Island Rab. Coll Antropol 2007, 31(Suppl 1):39-41

44. Austin P, Jakobiec FA, Iwamoto T: Elastodysplasia and elastodystrophy as the pathologic bases of ocular pterygia and pinguecula. Ophthalmology 1983, 90:96-109

45. D'Alena P, Wood IS: Labrador keratopathy: a microscopic study. Am J Ophthalmol 1972, 74:430-435

46. Johnson GJ, Overall M: Histology of spheroidal degeneration of the cornea in Labrador. Br J Ophthalmol 1978, 62:53-61

47. Menegay M, Lee D, Tabbara KF, Cafaro TA, Urrets-Zavalia JA, Serra $\mathrm{HM}$, Bhattacharya SK: Proteomic analysis of climatic keratopathy droplets. Invest Ophthalmol Vis Sci 2008, 49:2829-2837

48. Ansari MW, Rahi AH, Shukla BR: Pseudoelastic nature of pterygium, Br J Ophthalmol 1970, 54:473-476

49. Wang IJ, Hu FR, Chen PJ, Lin CT: Mechanism of abnormal elastin gene expression in the pinguecular part of pterygia. Am J Pathol 2000, 157:1269-1276

50. Coroneo MT: Albedo concentration in the anterior eye: a phenomenon that locates some solar diseases. Ophthalmic Surg 1990 $21: 60-66$
51. Dushku N, Reid TW: Immunohistochemical evidence that human pterygia originate from an invasion of vimentin-expressing altered limbal epithelial basal cells. Curr Eye Res 1994, 13:473-481

52. Duke-Elder S, Wybar KC (Ed): The Anatomy of the Visual System. System of Ophthalmology 2. London: Kimpton, 1961, p 557

53. Grossniklaus HE, Green WR, Luckenbach M, Chan CC: Conjunctival lesions in adults: a clinical and histopathologic review. Cornea 1987, 6:78-116

54. Basti S, Macsai MS: Ocular surface squamous neoplasia: a review. Cornea 2003, 22:687-704

55. Lee GA, Hirst LW: Ocular surface squamous neoplasia. Surv Ophthalmol 1995, 39:429-450

56. Pola EC, Masanganise R, Rusakaniko S: The trend of ocular surface squamous neoplasia among ocular surface tumour biopsies submitted for histology from Sekuru Kaguvi Eye Unit, Harare between 1996 and 2000. Cent Afr J Med 2003, 49:1-4

57. Nkomazana O, Tshitswana D: Ocular complications of HIV infection in sub-Sahara Africa. Curr HIV/AIDS Rep 2008, 5:120-125

58. Ng J, Coroneo MT, Wakefield D, Di Girolamo N: Ultraviolet radiation and the role of matrix metalloproteinases in the pathogenesis of ocular surface squamous neoplasia. Invest Ophthalmol Vis Sci 2008, 49:5295-5306

59. Oren M: Decision making by p53: life, death and cancer. Cell Death Differ 2003, 10:431-442

60. Dushku N, Reid TW: P53 expression in altered limbal basal cells of pingueculae, pterygia, and limbal tumors. Curr Eye Res 1997, 16: 1179-1192

61. Dushku N, Hatcher SL, Albert DM, Reid TW: p53 expression and relation to human papillomavirus infection in pingueculae, pterygia, and limbal tumors. Arch Ophthalmol 1999, 117:1593-1599

62. Tan DT, Lim AS, Goh HS, Smith DR: Abnormal expression of the p53 tumor suppressor gene in the conjunctiva of patients with pterygium. Am J Ophthalmol 1997, 123:404-405

63. Guthoff R, Marx A, Stroebel P: No evidence for a pathogenic role of human papillomavirus infection in ocular surface squamous neoplasia in Germany. Curr Eye Res 2009, 34:666-671

64. Ateenyi-Agaba C, Dai M, Le Calvez F, Katongole-Mbidde E, Smet A, Tommasino M, Franceschi S, Hainaut P, Weiderpass E: TP53 mutations in squamous-cell carcinomas of the conjunctiva: evidence for UV-induced mutagenesis. Mutagenesis 2004, 19:399-401

65. Schneider BG, John-Aryankalayil M, Rowsey JJ, Dushku N, Reid TW: Accumulation of $p 53$ protein in pterygia is not accompanied by TP53 gene mutation. Exp Eye Res 2006, 82:91-98

66. Shields JA, Shields CL, Mashayekhi A, Marr BP, Benavides R, Thangappan A, Phan L, Eagle RC Jr: Primary acquired melanosis of the conjunctiva: risks for progression to melanoma in 311 eyes. The 2006 Lorenz E. Zimmerman lecture. Ophthalmology 2008, 115:511519.e2

67. Shields CL, Demirci H, Karatza E, Shields JA: Clinical survey of 1643 melanocytic and nonmelanocytic conjunctival tumors. Ophthalmology 2004, 111:1747-1754

68. Sugiura M, Colby KA, Mihm MC Jr, Zembowicz A: Low-risk and high-risk histologic features in conjunctival primary acquired melanosis with atypia: clinicopathologic analysis of 29 cases. Am J Surg Pathol 2007, 31:185-192

69. Folberg R, McLean IW, Zimmerman LE: Primary acquired melanosis of the conjunctiva. Hum Pathol 1985, 16:129-135

70. Bongiorno MR, Lodato G, Affronti A, Aragona F, Arico M: Amelanotic conjunctival melanoma. Cutis 2006, 77:377-381

71. Tatla T, Hungerford J, Plowman N, Ghufoor K, Keene M: Conjunctival melanoma: the role of conservative surgery and radiotherapy in regional metastatic disease. Laryngoscope 2005, 115:817822

72. Sharara NA, Alexander RA, Luthert PJ, Hungerford JL, Cree IA: Differential immunoreactivity of melanocytic lesions of the conjunctiva. Histopathology 2001, 39:426-431

73. Jakobiec FA, Bhat $P$, Colby KA: Immunohistochemical studies of conjunctival nevi and melanomas. Arch Ophthalmol 2010, 128 : $174-183$

74. Furusato E, Hidayat AA, Man YG, Auerbach A, Furusato B, Rushing EJ: WT1 and Bcl2 expression in melanocytic lesions of the 
Ophthalmic Pterygium 827 AJP February 2011, Vol. 178, No. 2

conjunctiva: an immunohistochemical study of 123 cases. Arch Ophthalmol 2009, 127:964-969

75. Tabin G, Levin S, Snibson G, Loughnan M, Taylor H: Late recurrences and the necessity for long-term follow-up in corneal and conjunctival intraepithelial neoplasia. Ophthalmology 1997, 104:485-492

76. Kim JW, Abramson DH: Topical treatment options for conjunctival neoplasms. Clin Ophthalmol 2008, 2:503-515
77. Schechter BA, Koreishi AF, Karp CL, Feuer W: Long-term follow-up of conjunctival and corneal intraepithelial neoplasia treated with topical interferon alfa-2b. Ophthalmology 2008, 115:1291-1296

78. Skippen B, Tsang HH, Assaad NN, Coroneo MT: Rapid response of refractory ocular surface dysplasia to combination treatment with topical all-trans retinoic acid and interferon alfa-2b. Arch Ophthalmo 2010, 128:1368-1369 